\title{
Economic Value A Dried Fish Business Development in Bengkulu City
}

\author{
Bambang Sumantri, Agus Purwoko, Sriyoto, Ketut Sukiyono, and Eko \\ Sumartono
}

Department of Agricultural Socio-Economics, Faculty of Agriculture, University of Bengkulu, Indonesia

\begin{abstract}
The study aims to analyze the economic value of dried fish business by considering its added value of Hayami and marketing. This study uses primary data by surveying 55 dried fish producers in Bengkulu city. The results show that the average output price of dried fish is Rp6,586.61/kg. Using formula of Hayami's added value, the average added value gained is $\mathrm{Rp} 3,486.14 / \mathrm{kg}$. This informs that every a kilogram of fresh fish processed into dried fish will create added value of Rp3,486.14. When labor under consideration, labor added value in fish dried industries is Rp651.37 informing that an average of labor income for every kilogram of fish dried produced. The research also found that there are four patterns of marketing channels. From weekly average production of dried fish, i.e., $4,345 \mathrm{~kg}, 43.73 \%$ is distributed to big traders while the remaining, $56.27 \%$, is consumed directly. From big traders, dried fish are then distributed through three channel, namely, (1) $43.11 \%$ are marketed to the first intermediate trader, then, to intercity merchants, retailers and end customers in Bengkulu city, (2) $26.32 \%$ are distributed to second intermediate trader who then marketed to retailers and end customers; and (3) 31.58 $\%$ are marketed to third intermediate trader who, then, market to the intercity merchants and consumers. Marketing margins of this dried fish is $\mathrm{Rp} 1,000 / \mathrm{kg}$ from producers to traders and $\mathrm{Rp} 2,000 / \mathrm{kg}$ per $\mathrm{kg}$ of fish from traders to retailers.
\end{abstract}

Keywords: added value, dried fish, marketing channel, marketing margin

Received 16 May 2018 | Revised 04 August 2018 | Accepted 13 August 2018

\section{Introduction}

Located in Bengkulu province, Bengkulu city is directly adjacent to Indian Ocean. It is not surprisingly that Bengkulu city has huge potential captured fish production with various big and small pelagic fish, demersal and other marine biota. If the average consumption of fish in Bengkulu is $29.04 \mathrm{~kg} /$ year per capita, the need for fish consumption is to $7,727,369.76 \mathrm{~kg}$ or a total of 7,727.37 tons per year. This means that statistically, the fish consumptions in Bengkulu City are able to fulfill with its fish potential and even excessive. This means that if the production of overfishing then to increase the economic value of the city of Bengkulu dried fish still have a huge opportunity.

\footnotetext{
*Corresponding author at: Department of Agricultural Socio-Economic, Faculty of Agriculture, University of Bengkulu, Jl. WR. Supratman Kandang Limun, Bengkulu, Indonesia

E-mail address: bsumantri1719@yahoo.com,eko_sumartono@unib.ac.id
} 
In Bengkulu city, high value fresh fish are sold directly to consumers, while the les value fish mostly processed into dried fish in order to get an added value. However, these dried fish are only able to provide economic value if these products are consumed by consumers. The distribution of dried fish can be through many marketing patterns from producers to consumers. The distribution of processed fresh fish produced have been distributed to various cities in South Sumatra as well as in Bengkulu province. This distribution would involves many marketing channels impacting on consumer prices. For that reason, research aimed at quantifying economic value of fish processing business is not worthy to be conducted.

Research on quantifying economic value of fish processing focus mainly on two aspects. First aspect is estimating the product or fish value added, which can be meansured by the difference between input costs and output value. Value-added fish can be also explained as adding something to fish that is enable to increase profit margin and estimated by looking at the difference between input costs and output value. Value-added is all the additional value created at a certain stage by production factors, including tangible added value through the transformation of raw materials, labor and capital goods, and there is no visible value added due to the exchange relationship [1]. This value-added fish is frequently estimated by Hayami method of value-added measurement [2]. Many research have been done at various locations and scales on economic value, among others [3], [4], [5], [6], dan [7], as well as research by Sukiyono [8]. Second aspect is marketing including marketing channel, distribution and margin. Many researchers suggest that an increasingly significant marketing of many factors will bring changes to the business. For example the existence of a marketing channel will identify the creation of fish customers. In reducing inefficiencies in the marketing system through innovative interventions will help to understand the marketing margin. This approach has been applied to analyze marketing of various agricultural products including research by [9] and [10] for fishery products market and [11] for marketing fishery products relationship. Based on this discussion, the research aims to quantify the economic value of the dried fish business activities by analyzing the marketing channel, distribution and margins as well as estimate added value created from processing to marketing.

\section{Methods}

This research was conducted in the district of Kampung Melayu, Bengkulu City by surveying 55 households from total of 125 households who processed fresh fish into dried fish. A research [2] approach of added value was used to determine of added value of processed fish. Calculated the marketing margin, the price data used is the price at the farm level and price at the marketing agency level, so the formula is used:

$$
\mathrm{Mi}=\mathrm{Psi}-\mathrm{Pbi}
$$


Where: Mi $=$ i-level marketing margin; Psi $=$ market selling price at level $\mathrm{i} ; \mathrm{Pbi}=$ Market buying price at level $\mathrm{i}$

The trading margin can also be calculated from the sum of the costs and benefits of each marketing agency. Mathematically formulated as follows [12]:

$$
\mathrm{Mi}=\mathrm{Ci}+\pi \mathrm{i}
$$

Note: $\mathrm{Ci}=$ Cost of marketing institutions at level $\mathrm{i} ; \pi \mathrm{i}=$ The profit of marketing institutions at the i-th level. Of the two equations, it is obtained that:

$$
\text { Psi }-\mathrm{Pbi}=\mathrm{Ci}+\pi \mathrm{i}
$$

Therefore, the profit of marketing institutions at the level of-i for:

$$
\pi \mathrm{i}=\mathrm{Psi}-\mathrm{Pbi}-\mathrm{Ci}
$$

With this approach, added value, output value and profit as well as owner compensation factors

\begin{tabular}{|c|c|c|}
\hline Variables & Unit & Notation \\
\hline \multicolumn{3}{|c|}{ Output, Input, Price } \\
\hline Output & $\mathrm{Kg}$ & A \\
\hline Raw Material & $\mathrm{Kg}$ & B \\
\hline Labor & Man Working Hour (mwh) & $\mathrm{C}$ \\
\hline Convertions Factors & & $\mathrm{D}=\mathrm{A} / \mathrm{B}$ \\
\hline Labor Coefficient & $\mathrm{mwh} / \mathrm{kg}$ & $\mathrm{E}=\mathrm{C} / \mathrm{B}$ \\
\hline Output Price & $\mathrm{Rp} / \mathrm{kg}$ & $\mathrm{F}$ \\
\hline Labor Wages & $\mathrm{Rp} / \mathrm{mwh}$ & G \\
\hline \multicolumn{3}{|c|}{ Revenue and profits } \\
\hline Raw Materials Price & $\mathrm{Rp} / \mathrm{kg}$ & $\mathrm{H}$ \\
\hline Other Input Prices & $\mathrm{Rp} / \mathrm{kg}$ & I \\
\hline OutputValue & $\mathrm{Rp} / \mathrm{kg}$ & $\mathrm{J}=\mathrm{D} \times \mathrm{F}$ \\
\hline Value-added & $\mathrm{Rp} / \mathrm{kg}$ & $\mathrm{K}=\mathrm{J}-\mathrm{I}-\mathrm{H}$ \\
\hline Ratio of Value Added & $\%$ & $\mathrm{~L}=\mathrm{K} / \mathrm{J} \times 100 \%$ \\
\hline Labor Revenue & $\mathrm{Rp} / \mathrm{kg}$ & $M=E \times G$ \\
\hline LaborShare & $\%$ & $N=M / K \times 100 \%$ \\
\hline Profit & $\mathrm{Rp} / \mathrm{kg}$ & $\mathrm{O}=\mathrm{K}-\mathrm{M}$ \\
\hline Profitability & $\%$ & $\mathrm{P}=\mathrm{O} / \mathrm{J} \times 100 \%$ \\
\hline \multicolumn{3}{|c|}{ Owner Compensation Factors of Production } \\
\hline Margin & $\mathrm{Rp}$ & $\mathrm{Q}=\mathrm{J}-\mathrm{H}$ \\
\hline a. Labor & $\%$ & $\mathrm{R} \%=\mathrm{M} / \mathrm{Q} \times 100 \%$ \\
\hline b. Capital & $\%$ & $\mathrm{~S} \%=\mathrm{I} / \mathrm{Q} \times 100 \%$ \\
\hline c. Profit & $\%$ & $\mathrm{~T} \%=\mathrm{O} / \mathrm{Q} \times 100 \%$ \\
\hline
\end{tabular}
of production can be estimated. Table 1 presents Hayami method of added value measurement.

Table 1. Hayami Method of Added Value Measurement

Source: [2]

Marketing analysis consists of identifying marketing channels, estimating marketing distribution and marketing margin. A market channel is defined as a path traced in the direct or indirect transfer of product as it moves from a producer to an ultimate consumer. Thus, marketing channel refers to a way of making a product available to distribute to the end consumers. Marketing margin is an equilibrium entity that is a function of the difference 
between the equilibrium of retail and farm prices (Wohlgenant, (2001) in [13] and is a commonly used to measure of the performance of a marketing system (Abbott and Makeham, (1990) in [13]), or between export and farm prices [14]. Marketing margins provide neither a measure of farmers' well-being nor of marketing firms' performance. However, they give an indication of the performance of a particular industry (Tomek and Robinson, (1990) in [13], or an indication of the market's structure and efficiency. For instance, Gordon and Hazledine (1996), in [13] have argued and revealed in their study that the form of the market power is likely to manifest in larger marketing margins than would otherwise be the case. Marketing margins are the result of demand and supply factors, marketing costs, and the degree of marketing channel competition [15]. Thus, margins reflect aggregate processing and retailing firm behavior which influence the level and variability of farm prices and may influence the farmer's share of the consumer food dollar ((Gardner,1975; Tomek and Robinson, 1990; Wohlgenant, 1989) in [13].

In addition, [16] defined marketing margin as the price difference between two levels of the marketing margin multiplied by the quantity of product being marketed. This estimation is similar to added value concept. Therefore, the economic value of marketing margin is recognized as the price of a set of marketing services resulted from interaction between demand and supply of products. This implies that the value of marketing margins is divided into marketing costs and marketing charges.

\section{Results and Discussion}

\subsection{Marketing Channel and Product Distribution}

Marketing of dried fish involves two main actors, namely, collectors and retailers. Collectors are operators who play the area to buy dried fish from producers and resell to retailers. Retailers are those who buy in small quantities either directly at the market from producers or from and collectors. From survey, retailers buy dried fish from collectors and resell directly to end consumers whether consumers are located in Bengkulu city or out of Bengkulu city. Four marketing channel patterns are identified in this research, i.e.:

a. Pattern 1: Dried fish producers - End consumers in Bengkulu City.

b. Pattern 2: Dried fish producers - Collector mercant in Bengkulu City (involving 3 collector merchants) - End Consumers in Bengkulu City.

c. Pattern 3: Dried fish producers - Collector mercant in Bengkulu City - Retailer in Bengkulu City - End consumers.

d. Pattern 4: Dried fish producers - Collector mercant in Bengkulu City - Inter City traders Outer city consumers. 
In this research, dried fish selling to out of Bengkulu city are not investigated. As a result, marketing margin and marketing profit for marketing channel pattern 4 are not able to be estimated. Figure 1 presents Marketing Channel and product distribution among channels.

Figure 1 shows that most of dried fish produced are marketed directly to end consumers in Bengkulu city amounted $56.27 \%(2,445 \mathrm{~kg})$ of total dried fish produced per week. The remaining, $43.73 \%$ or $1,900 \mathrm{~kg}$ are sold to collector merchants in Bengkulu City which are, then, distributed to local retailer $(2.10 \%$ or $40 \mathrm{~kg}))$, Out of Bengkulu city traders $(72.37 \%$ or $1,375 \mathrm{~kg}$ ), and end consumers in Bengkulu City (25.53\% or $485 \mathrm{~kg})$. It should be noted that collector merchant in Bengkulu city involve 3 merchants who are able to market $800 \mathrm{~kg}$ (42.11\%), $500 \mathrm{~kg}(26.32 \%)$, and $600 \mathrm{~kg}$ (31.58\%) for collector merchant 1, collector merchant 2 , and collector merchant 3 respectively. In this area, most dried fish producers have mutual relationship with the traders not only in term of marketing aspects, but also in production aspects. The traders usually provide drying site that can be leased by dried fish producers. This drying site is made of nylon nets (called waring) with size 1.5 × 6 meter and rented Rp10,000 per site per day.

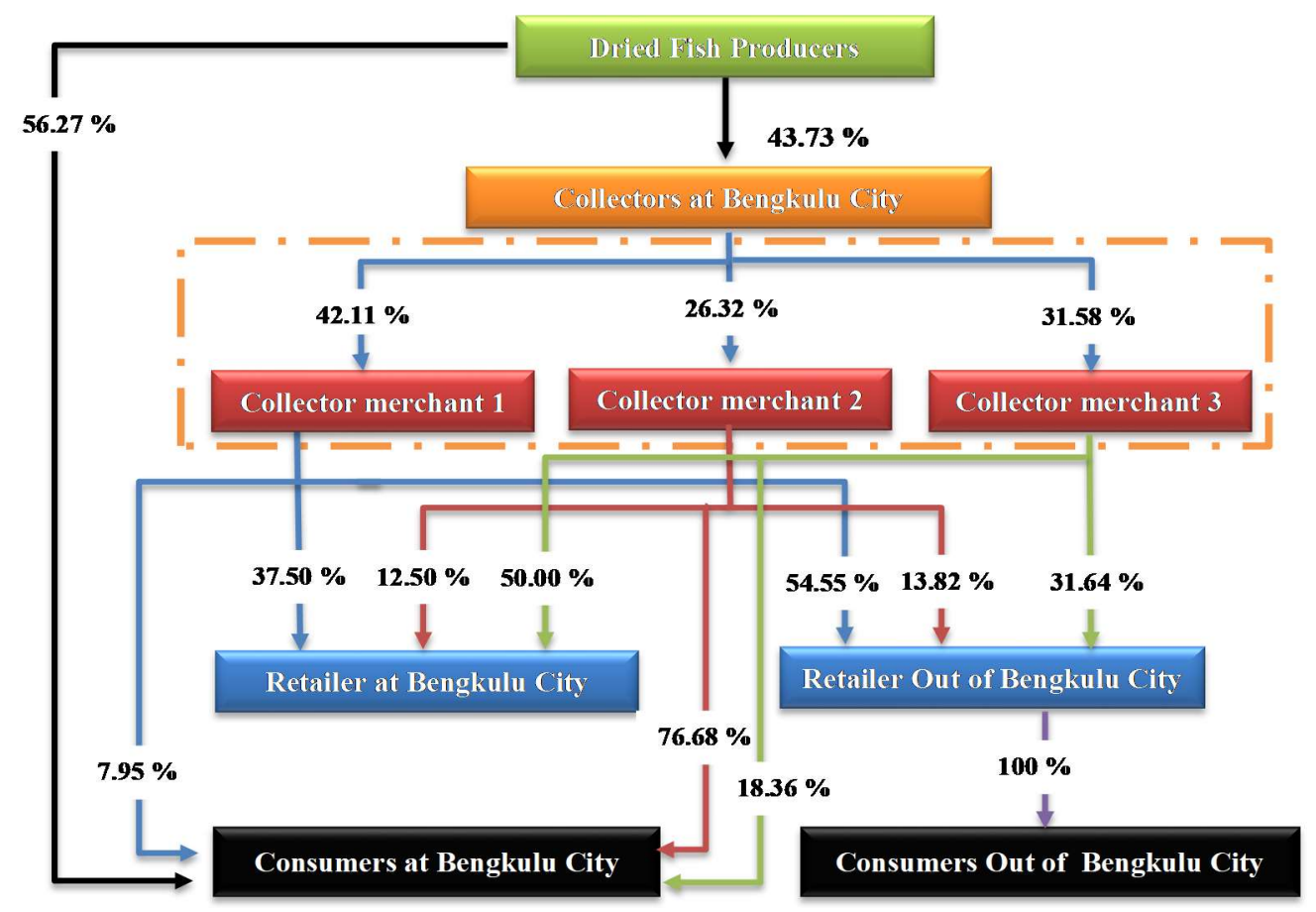

Figure 1. Marketing Distribution of Dried Fish in Bengkulu City

Note: this research only focus on Bengkulu city market

\subsection{Marketing Costs and Margins of Dried Fish}

Distribution dried fish from the producer to the consumer involves costs resulting from activities carried out since initial step in dried fish processing such as labor costs, depreciation, and among others. These costs incurred are different for each type of fish processed into dried 
fish. Fresh fish of Sea perch, for instance, has the lowest price than other fish types and does not need ice for maintaining its freshness before processing into dried fish. In addition, every type of dried fish has also different selling price. The highest selling price is anchovy and sea perch. On average, the selling price of dried fish is Rp14,333.33/ $\mathrm{kg}$ while the purchased price of fresh fish is Rp3,833.33/kg. Table 2 present average marketing cost and margins for each marketing pattern identified in survey.

Marketing cost in marketing channel I (from dried fish producers to end consumers in Bengkulu city) only consists of production cost of dried fish. It does not incur marketing cost, such as transportation cost since the consumers buy directly to their location. Meanwhile in marketing channel II (dried fish producers - collector merchants - end Consumers); and channel III (dried fish producers - collector merchants - retailers - end Consumers), they have to incur marketing costs including cost of packaging, depreciation transportations its means a reduction in the value of an asset with the passage of time, due in particular to wear and tear, as well as transportation cost to deliver dried fish from producers to end consumers. Total marketing costs are incurred of Rp5,767.11,- and Rp6,174.58,- for channel II and III respectively.

Table 2. Marketing Costs and Margins of Dried Fish for each Pattern in Bengkulu City

\begin{tabular}{|c|c|c|c|}
\hline \multirow{2}{*}{ Description } & \multicolumn{3}{|c|}{ Marketing Channel Pattern } \\
\hline & I & II & III \\
\hline \multicolumn{4}{|l|}{ Dried Fish Producers } \\
\hline Raw Material Costs & $3,833.33$ & $3,833.33$ & $3,833.33$ \\
\hline Labor Cost & $1,511.91$ & $1,511.91$ & $1,511.91$ \\
\hline \multicolumn{4}{|l|}{ Other inputs' cost } \\
\hline - Salt & 174.20 & 174.20 & 174.20 \\
\hline- Ice & 15.20 & 15.20 & 15.20 \\
\hline Total Cost & $5,534.64$ & $5,534.64$ & $5,534.64$ \\
\hline Selling price & $14,333.33$ & $14,333.33$ & $14,333.33$ \\
\hline \multicolumn{4}{|c|}{ Intermediate Collectors/Collecting merchants } \\
\hline Purchased dried fish price & & $14,333.33$ & \\
\hline The cost of packaging & & 70.44 & \\
\hline Total Cost & & 70.44 & \\
\hline Selling Price & & $20,844.44$ & \\
\hline Margin & & $6,511.11$ & \\
\hline Profit margin & & $6,440.67$ & \\
\hline \multicolumn{4}{|l|}{ Retailers } \\
\hline Purchased dried fish price & & $20,844.44$ & $14,333.33$ \\
\hline Transportation costs & & 87.54 & 557.41 \\
\hline Total Cost & & 87.54 & 557.41 \\
\hline Selling Price & & $23,425.76$ & $20,022.22$ \\
\hline Margin & & $2,581.32$ & $5,688.89$ \\
\hline Profit Margin & & $2,493.78$ & $5,131.48$ \\
\hline \multicolumn{4}{|l|}{ Consumers } \\
\hline Purchased dried fish price & $22,424.46$ & $23,425.76$ & $20,022.22$ \\
\hline Total marketing costs & 0.00 & 157.98 & 557.41 \\
\hline Total profit margin & $8,091.13$ & $8,934.45$ & $5,131.48$ \\
\hline Total Margin & $8,091.13$ & $9,092.43$ & $5,688.89$ \\
\hline
\end{tabular}

Source: primary data analyzed, 2015 
The difference between the price paid by consumers for these products and prices received by producers of dried fish called marketing margin. It is found that marketing margin in channel I is the highest. This finding is reasonable since they produce and sell their products by themselves and do not incur any marketing cost. This finding differs from channel II and III in which their marketing margin also comprise dried fish and transportation cost. Even though they have the lower marketing margin, their marketing margin still have positive value. This indicates that the dried fish marketing is profitable. Over all, this result also informs that this business is feasible to operate.

\subsection{Added Value of Dried Fish}

Activities in the dry fish processing process can provide economic value for dried fish producers. It should be noted that the calculation of economic value is approximated by calculating the added value disregard fish types. According to Bailey and Jayson (2008) added value can be created from marketing channel activities. On average, added value of dried fish processing is presented in Table 3 .

From Table 3, some interesting findings can be summarized as follows:

\section{a. Added Value for Dried Fish Processors}

An average working hours of labor (meassured by man working hour $=m w h$ ) for processing dried fish is 3.4 hours per week. From analysis, it is found that an average labor coefficient is $0.04 \mathrm{mwh} / \mathrm{kg}$ informing that for every $\mathrm{kg}$ fresh fish processing into dried fish, labor working hour required is 0.04 hour.

Two categories inputs used for dried fish processing, namely, fresh fish (raw material) costing of Rp4,186.18/kg and other inputs (ice and salt) costing of Rp103.66 per $\mathrm{kg}$ of fish dried. The average price of dried fish is Rp19,284.65/kg. Multiplying output price with a conversion factor results in output value of Rp6,586.61 per kg.

An average value added is $\mathrm{Rp} 3,486.13$ per $\mathrm{kg}$ meaning that every $\mathrm{kg}$ of fresh fish processed into dried fish will create added value of Rp3,486.13. This added value is gross added value because it comprises labor revenue of Rp709.75 per $\mathrm{kg}$. This labor revenue is similar to $16.27 \%$ of value added created. This also informs that the profit gained from every kg dried fish is Rp3,256.67 or $37.75 \%$ of total output value.

The production Margin is $\mathrm{Rp} 3,546.02$ per $\mathrm{kg}$ consisting of labor, other inputs, and profit margins. The highest margin is profit margin of $72.44 \%$ followed by labor and othe inputs margin of $15.90 \%$ and $4.1 \%$ respectively. 
Table 3. Average Value Added of Dried Fish Business

\begin{tabular}{|c|c|c|c|c|}
\hline \multirow{2}{*}{ Value added Variable } & \multirow{2}{*}{ Unit } & \multicolumn{3}{|c|}{ Marketing Channel } \\
\hline & & $\mathbf{I}$ & II & III \\
\hline \multicolumn{5}{|c|}{ Output, Input and Price } \\
\hline Output & $\mathrm{Kg}$ & 30,50 & & \\
\hline Raw Material & $\mathrm{Kg}$ & 107,92 & & \\
\hline Labor & $M w h$ & 3,40 & & \\
\hline Convertions Factors & & 0.42 & & \\
\hline Labor coefficient & $m w h / \mathrm{kg}$ & 0.04 & & \\
\hline Output Price & $\mathrm{Rp} / \mathrm{kg}$ & $19.284,65$ & & \\
\hline Labor Wages & $\mathrm{Rp} / m w h$ & $3,486.95$ & & \\
\hline \multicolumn{5}{|c|}{ Revenue and Profits } \\
\hline \multicolumn{5}{|l|}{ Raw Material } \\
\hline - Volume & $\mathrm{Kg}$ & & & \\
\hline - Price & $\mathrm{Rp} / \mathrm{kg}$ & $4,186.18$ & $21,833.33$ & $21,250.00$ \\
\hline Other Input Prices & $\mathrm{Rp} / \mathrm{kg}$ & 103.66 & & \\
\hline Marketing Cost & $\mathrm{Rp} / \mathrm{Kg}$ & & 10.709 .73 & $7,732.00$ \\
\hline - Packaging and depreciation & & & 918.07 & 683.38 \\
\hline - Labor wages & & & $9,791.66$ & $7,048.62$ \\
\hline Output Prices & $\mathrm{Rp} / \mathrm{kg}$ & $6,586.61$ & $36,000.00$ & 25,000 \\
\hline Value Added & $\mathrm{Rp} / \mathrm{kg}$ & $2,296.77$ & $13,248.60$ & $3,066.62$ \\
\hline Value Added Ratio & $\%$ & 34,87 & 36.80 & 12.26 \\
\hline Labor Income & $\mathrm{Rp} / \mathrm{kg}$ & 139.478 & 391.67 & 281.94 \\
\hline Labor Share & $\%$ & 6.07 & 2.96 & 9.19 \\
\hline Profit & $\mathrm{Rp} / \mathrm{kg}$ & $2,157.29$ & $12,856.93$ & $2,784.68$ \\
\hline Profitable level & $\%$ & 93.93 & 97.04 & 90.81 \\
\hline \multicolumn{5}{|c|}{ Owner Compensation Factors of Production } \\
\hline Margin & $\mathrm{Rp}$ & $2,400.43$ & $14,166.67$ & $3,750.00$ \\
\hline a. Labor & $\%$ & 5.81 & 2.76 & 7.52 \\
\hline b. Capital & $\%$ & 4.32 & 0.00 & 0.00 \\
\hline c. Marketing Cost & $\%$ & 0 & 6.48 & 18.22 \\
\hline d. Profit & $\%$ & 89.87 & 90.75 & 74.26 \\
\hline
\end{tabular}

Note: $\mathrm{mwh}=$ man working hour

Source: Primary Data Analysed (2015)

\section{b. Added Value of Dried Fish Marketing in Channel II}

Marketing Channel II involves distribution of dried fish from producers, collector merchants, and end consumers in Bengkulu City. Implying, value added measurements focus on costs that accompanies activities of distributing products from producers to end consumers. From Table 3, it can be summarized as follows:

The highest cost incurred by collecting merchants is raw material (dried fish product bought from producers). They have to pay $\mathrm{Rp} 21,833.33$ per $\mathrm{kg}$, followed by marketing cost of Rp10,709.73. Marketing cost incurred in pattern II consist of packaging and depreciation cost and labor wages. 
Added value generated aproximately is Rp.13,248.60 for each $\mathrm{kg}$ distributed from producers to consumers. This added value is gross added value due to labor incomes that have to paid. This labor income is aproxiately Rp391.67 with share of $2.96 \%$

Marketing margin created is Rp14,166.67 per $\mathrm{kg}$. This value involve $90.75 \%$ of profit margin, $6.48 \%$ of marketing cost, and $2.76 \%$ of labor.

\section{c. Added Value of Dried Fish Marketing in Channel III}

Marketing channel III involves distribution of dried fish from producers to end consumers in Bengkulu city through collector merchants and retailers. In this channel, retailers get their products from collecting merchants. Some interesting findings in this channel can be summarized as follows:

Price paid by retailers for fish dried products cheaper than those collecting merchants on average. The main reason is that they buy in large quantities and from many suppliers (collecting merchants). Retailers pay Rp21,833.33 while collecting merchants have to pay Rp21,833.33 for every kg they bought.

Margin formed on this channel is smaller than the margin on channel 2. If channel 2 is able to create margin of Rp14,166.67, Channel 3 only creates Rp3,750.00 per $\mathrm{kg}$ fish dried sold. This means that channel 2 only able to generate $90.81 \%$ of profitable level. This profitable level is the lowest among channels. This margin is distributed to Labor $7.52 \%$, marketing cost $18.11 \%$ and profit take the highest margin, i.e., $74.26 \%$.

Added value generated from this channel is Rp3,066.62 or $12.26 \%$. This added value is formed from labor income of Rp281.94 or $9.19 \%$ and profit Rp2,784.68 or $90.81 \%$.

\section{Conclusions and Implications}

Primary channel of dried fish consist of producers, collecting merchants, and retailers. Four main channels are identified from this research, namely, producers to end consumers; producers - collecting merchants - end consumers; producers - collecting merchants - retailers - end consumers; and producers - collecting merchants - retailers - out of Bengkulu city consumers in which the first three channels are analyzed in this paper. The various marketing margins are created from each channels in which channel 1 (producers to end consumers) creates the highest marketing margin followed by channel 2 and 3 .

Dried fish producers process fresh fish collected from fishermen. Fresh fish is the main inputs used by producers combined with salt and iced as additional inputs to produce dried fish with conversion factors of $0.42 \%$. However, producers are only able to generate the lowest added value among marketing actors. 
Maximizing economic value and profits, dry fish producers must provide storage or containers to store their products, so they can manage their marketing strategies to get maximum profit. This storage can be managed by producer groups or producer cooperatives. Manufacturers or marketers can expand their markets not only in the domestic market but also in export markets. Increase market access to credit or funding institutions to expand and improve the economies of scale in the production and marketing of dried fish.

\section{Acknowledgments}

This article was written based on the results of the study entitled "Enhancing Competitiveness Strategy for Fish Processing Industry City of Dry In Bengkulu". DIPA research was funded by the Ministry for Research, Technology and Higher Education No. 042.06-0/2016, dated December 7, 2015. Therefore, researchers are grateful to the Ministry of Research, Technology and Higher Education through the University of Bengkulu.

\section{REFERENCES}

[1] T. Hines, Supply Chain Strategies: Customer-Driven and Customer-Focused. Great Britain, Elsevier Butterworth Heinemann, 2004.

[2] I. Y. Hayami, T. Kawagoe, Y. Morooka, and M. Siregar, "Agricultural Marketing and Processing in Upland Java a Perspective from a Sunda Village," Bogor: CGPRT Centre, 1987.

[3] Bank Indonesia, "Pola Pembiayaan UMKM Usaha Pengolahan Ikan Kering di Kota Bengkulu. Bank Indonesia cabang Bengkulu,” 2012.

[4] R. Purwaningsih, "Analisis nilai tambah produk perikanan Lemuru Pelabuhan Muncar Banyuwangi," Jurnal Ilmiah Teknik Industri. 2015. [Online]. Available: http://journals.ums.ac.id/index.php/jiti/article/view/620

[5] H. Malini and S. Oktarina, "Analisis keuntungan dan nilai tambah pengolahan kerupuk udang dan pemasarannya di Sungsang I Kecamatan Banyuasin II Kabupaten Banyuasin Sumatera Selatan," in Prosiding Seminar Nasional Lahan Suboptimal, 2014, pp. 240-249.

[6] I. P. R. Pramana, I. M. Sudarma, N. W. P. Artini, Nilai tambah produk olahan ikan salmon di PT Prasetya Agung Cahaya Utama, Kecamatan Kediri, Kabupaten Tabanan," Jurnal Agribisnis dan Agrowisata. 2015. [Online]. Available: https://ojs.unud.ac.id/index.php/JAA/article/view/17385

[7] D. Suryanto and E. Sumartono, "Analisis finansial usaha keramba jaring apung di perusahaan perseorangan Dobro," Jurnal AGRISEP. 2016. [Online]. Available: https://ejournal.unib.ac.id/index.php/agrisep/article/view/841

[8] K. Sukiyono, I. Cahyadinata, A. Purwoko, S. Widiono, E. Sumartono, N. N. Asriani, and G. Mulyasari, "Assessing smallholder household vulnerability to price volatility of palm fresh fruit bunch in Bengkulu Province," International Journal of Applied Business and Economic Research, vol. 15, no. 3, pp. 1-5, 2017.

[9] E. Lisna and Sofyan. Analisis efisiensi pemasaran produk agroindustri perikanan (Studi kasus pemasaran ikan teri) di Desa Meunasah Keudee Kabupaten Aceh Besar. Agrisep. 2011. [Online]. Available: http://www.jurnal.unsyiah.ac.id/agrisep/article/view/205

[10] J. Tubalawony, F. Wattimena, J. Latuihamallo, and J. Matakupan. Marketing Study of Dry Abalone [Haliotis asinina Linnaeus, 1758] in District of South East Maluku. Aquatic 
2016.

[Online].

Available: https://www.sciencedirect.com/science/article/pii/S2214241X16300414

[11] M. M. Romdhon and K. Sukiyono. Pola kemitraan pemasaran lobster di Kota Bengkulu. Jurnal AGRISEP. 2011. [Online]. Available: https://ejournal.unib.ac.id/index.php/agrisep/article/view/563

[12] R. W. Asmarantaka, Bunga Rampai Agribisnis Seri Pemasaran. Bogor: IPB Press, 2012.

[13] M. Abassian, Karim. MH (Karim Koshteh MH), M. Esmaeili, and H. Ebrahimzadeh, "The economic analysis of marketing margin of mazafati date: A case study of Sistan and Blouchestan-Iran," International Journal of Agriculture and Crop Sciences, vol. 4, no. 7, pp. 390-397, 2012.

[14] M. Carambas, 2005. Analysis of Marketing Margins in Eco-Labeled Products, Center for Developmemnt Research, University of Bonn. [Online]. Available: http://ageconsearch.umn.edu/bitstream/24600/1/pp05ca06.pdf

[15] J. M. Marsh and G. W. Brester, "Wholesale-Retail marketing margin behavior in the beef and pork industries," Journal of Agricultural and Resource Economics, vol. 29, no. 1, pp. 45-64, 2004.

[16] D. C. Dahl and J. W. Hamound, Market and Price Analysis: The Agricultural Industries. USA: Mc.Graw Hill. Book Company, 1977. 